\title{
Pemberdayaan masyarakat melalui alih teknologi pembuatan makanan tambahan berbahan baku konsentrat protein ikan di Pulau Cawan Indragiri Hilir
}

\author{
Bintal Amin*, Dewita, Dessy Yoswaty, dan Irvina Nurrachmi \\ Fakultas Perikanan dan Kelautan, Universitas Riau \\ *bintalamin@gmail.com
}

\begin{abstract}
Abstrak. Kegiatan pengabdian kepada masyarakat Desa Pulau Cawan Kabupaten Indragiri Hilir yang dilaksanakan berupa penyuluhan dan pelatihan secara umum bertujuan agar masyarakat, (terutama kader Pemberdayaan Kesejahteraan Keluarga atau PKK), mendapat keterampilan dalam pengolahan pangan ikani dan membuka usaha mandiri. Pemanfaatan dan pengembangan Pulau Cawan sebagai kawasan ekowisata perlu diikuti dengan kegiatan yang dapat memberikan peningkatan kesejahteraan masyarakat sekitarnya. Dengan terbukanya lapangan kerja baru tersebut maka pada akhirnya diharapkan dapat meningkatkan kesejahteraan keluarga. Melalui kegiatan penyuluhan dan pelatihan ini diharapkan juga agar pada saat produksi ikan melimpah atau harga ikan sedang jatuh, dapat diselamatkan dengan cara mengolahnya menjadi berbagai produk olahan berbahan ikan khususnya produk jajanan snack dan cookies yang bernilai ekonomi dan bergizi tinggi. Kegiatan yang pelaksanaannya dilakukan dengan kerjasama mahasiswa peserta Kuliah Kerja Nyata mendapatkan sambutan yang baik dari masyarakat desa, terutama kader PKK, Kepala Desa dan juga dari Kepala Dinas Kelautan dan Perikanan Kabupaten Indragiri Hilir. Dengan bantuan peralatan yang diberikan untuk memproduksi tiga jenis makanan yang diajarkan dalam pelatihan maka peserta kegiatan akan dapat memberdayakan kelompoknya untuk membuka usaha dalam membuat produk makanan berbasis ikan tersebut. Kepala Dinas Kelautan dan Perikanan bahkan berjanji akan memberikan bantuan lebih luas bagi pengembangan produksi yang dihasilkan tersebut, termasuk membantu sarana dan prasarana pemasarannya di wilayah Kabupaten Indragiri Hilir.
\end{abstract}

Kata kunci: makanan tambahan; pemberdayaan masyarakat; protein ikan; pulau cawan

\begin{abstract}
The devotion to the community of Pulau Cawan in Indragiri Hilir Regency carried out in the form of counseling and training which generally aimed at making the community, (especially the cadres of Family Welfare Empowerment or PKK), acquire skills in processing fish based food and creating new independent businesses. The use and development of Pulau Cawan as an ecotourism area needs to be followed by activities that can improve the welfare of the surrounding community. With the opening of new jobs, it is ultimately expected to improve family welfare. Through this extension and training activities, it is hoped that when fish catch and production abundant or fish prices are falling, it can be saved by processing them into various processed products made from fish, especially snacks and cookies which are of high economic value and nutritious. The current community empowerment activities received good reception and appreciation from the local community, the PKK cadres and Pulau Cawan Headmaster. All the participants confidently will empower their groups to create and start to open businesses in making these fish-based food products. The Head of Department of Maritime Affairs and Fisheries even promised to provide wider assistance for the development of the product, including its marketing.
\end{abstract}

Keywords: community empowerment; fish protein; pulau cawan; supplementary food

To cite this article: Amin, B., Dewita, D. Yoswaty, \& I. Nurrachmi. 2019. Pemberdayaan masyarakat melalui alih teknologi pembuatan makanan tambahan berbahan baku konsentrat protein ikan di Pulau Cawan Indragiri Hilir. Unri Conference Series: Community Engagement 1: 121-125. https://doi.org/10.31258/unricsce.1.121-125

(C) 2019 Authors

Peer-review under responsibility of the organizing committee of Seminar Nasional Pemberdayaan Masyarakat 2019 


\section{PENDAHULUAN}

Kabupaten Indragiri Hilir yang berada di bagian selatan Provinsi Riau Secara geografis berada pada koordinat $0^{\circ} 36^{\prime} \mathrm{LU}-1^{\circ} 07^{\prime} \mathrm{LS}$ dan $102^{\circ} 32^{\prime} \mathrm{BT}-104^{\circ} 10^{\prime} \mathrm{BT}$ dengan luas wilayah $18.812,97 \mathrm{Km}^{2}$ yang terdiri dari luas daratan 11.605,97 Km $\mathrm{Km}^{2}$, perairan laut 7.207 $\mathrm{Km}^{2}$, perairan umum $888,97 \mathrm{Km}^{2}$, laut $6.318 \mathrm{Km}^{2}$ dan memiliki garis pantai sepanjang 339,5 Km. Potensi perikanan tangkap yang ada di wilayah ini mencapai 111.212 ton per tahun. Saat ini potensi perikanan tangkap yang sudah dikembangkan di daerah itu tercatat sebanyak $50.386,88$ ton, sedangkan yang belum dimanfaatkan masih terdapat sebanyak $60.825,12$ ton atau sebesar 54,69 persen dari potensi yang ada. Selain memiliki potensi besar terhadap perikanan tangkap, Indragiri Hilir juga kaya akan potensi perikanan budidaya. Potensi budidaya air tawar di Indragiri Hilir meliputi kolam seluas 1.657 hektare dan keramba sebanyak 3500 unit. Dari potensi tesebut, saat ini baru sekitar 20\% yang dimanfaatkan (DKP Inhil, 2016).

Salah satu masalah gizi masyarakat Indonesia adalah masalah Kurang Energi Protein (KEP), yang berarti bahwa hingga saat ini di beberapa wilayah Indonesia, termasuk di Indragiri Hilir, masih terdapat masalah gizi buruk. Oleh karena itu, pemerintah berupaya mengatasi masalah tersebut melalui berbagai program antara lain Pemberian Makanan Tambahan/PMT pada anak balita. Dalam rangka ikut mensukseskan upaya pemerintah tersebut dibutuhkan beberapa upaya untuk menciptakan suatu produk yang bermutu tinggi terutama nilai gizi proteinnya. Hasil tangkapan ikan di Indragiri Hilir yang dijual langsung oleh nelayan harganya relatif murah, terutama pada musim-musim tertentu. Oleh karena itu, perlu dicarikan solusi sehingga disamping harganya tidak turun, produk ikan tersebut dapat dimanfaatkan untuk dijadikan sumber bahan baku dalam pengolahan konsentrat protein ikan (KPI) dan selanjutnya dimanfaatkan pada pembuatan makanan jajanan berprotein tinggi guna menunjang upaya pemerintah melalui PMT, mengingat tingkat kelarutan dan kecernaan KPI cukup tinggi (Dewita dan Syahrul, 2010). Menurut Adawyah (2007), dengan adanya diversifikasi produk olahan, memungkinkan pengembangan produk baru yang lebih diminati masyarakat, sehingga dapat meningkatkan nilai tambah produk olahan ikan tersebut.

Di Kabupaten Indragairi Hilir penderita gizi buruk masih menjadi permasalahan. Pada tahun 2016 bahkan menjadi kabupaten dengan kasus gizi buruk tertinggi di Provinsi Riau dengan 21 kasus (Potretnews.com, 19 April 2016). Oleh karena itu, mengingat potensi dan produksi perikanan derah ini cukup tinggi, maka salah satu kegiatan yang paling logik untuk dilakukan dalam upaya memanfaatkan produksi ikan tersebut dan dalam upaya meningkatkan nilai tambah, mengurangi resiko fluktuasi harga serta mengatasi gizi buruk adalah penanganan pascapanen melalui diversifikasi produk berbasis ikan, khususnya KPI. Kegiatan penyuluhan dan pengabdian ini dilakukan dengan alih teknologi pembuatan makanan jajanan berbahan baku konsentrat protein ikan dan selanjutnya dijadikan sebagai produk makanan tambahan anak balita gizi kurang. Sesuai dengan pendapat Manley (2000), diharapkan melalui produk tersebut dapat menjadi solusi untuk mengatasi permasalahan gizi kurang pada anak balita di Kabupaten Indragiri Hilir sekaligus sebagai matapencaharian tambahan bagi meningkatkan penghasilan sebagian masyarakat.

\section{METODE PENERAPAN}

Kegiatan penyuluhan tentang pemberdayaan masyarakat lokal di Pulau Cawan Kabupaten Indragiri Hilir Provinsi Riau merupakan kegiatan sebelumnya berupa pengembangan usaha ekowisata mangrove yang diintegrasikan dengan kegiatan pembibitan magrove dan pembuatan sirup dan wajik berbahan baku buah mangrove. Dengan demikian maka tindak lanjutnya adalah dengan melakukan kegiatan alih teknologi pembuatan makanan jajanan dengan gizi tinggi berbahan baku konsentrat protein ikan.

Metode pelaksanaan kegiatan pengabdian dilakukan dengan metode berbasis kelompok (Syahrul et al., 2018), mulai dari menyediakan sarana dan prasarana usaha, meningkatkan keterampilan sumberdaya manusia (SDM) melalui pelatihan, serta penguatan kelompok. Selama kegiatan penyuluhan dilakukan pendampingan untuk mengukur ketercapaian target dan luaran. Hasil dari kegiatan ini adalah meningkatnya kompetensi kelompok masyarakat di Pulau Cawan dalam pembuatan produk olahan makanan berbahan dasar ikan dan sekaligus menjadi makanan khas dari Pulau Cawan.

Metode kegiatan yang diterapkan pada kegiatan ini adalah dalam bentuk pelatihan yaitu ceramah, demonstrasi/peragaan dan praktek berwirausaha. Proses kegiatan mulai dari persiapan, rekruitmen calon peserta dan pelaksanaan pelatihan dan monitoring dilakukan selama 4 bulan. Hasil yang diharapkan adalah terwujudnya usaha pembuatan makanan jajanan berprotein tinggi berbahan baku ikan untuk meningkatkan pendapatan masyarakat lokal di Pulau Cawan. Kegiatan praktek pembuatan makanan berbahan ikan dilakukan di Kantor Kepala Desa Pulau Cawan (Gambar 1), sedangkan materi yang berkaitan dengan hal tersebut dan persiapan 
pengadaan alat dan bahan dilakukan satu bulan sebelumnya dimana koordinasi dengan masyarakat dan perangkat desa sebagiannya dilakukan oleh mahasiswa Kuliah Kerja Nyata di desa tersebut dengan panduan dari tim.
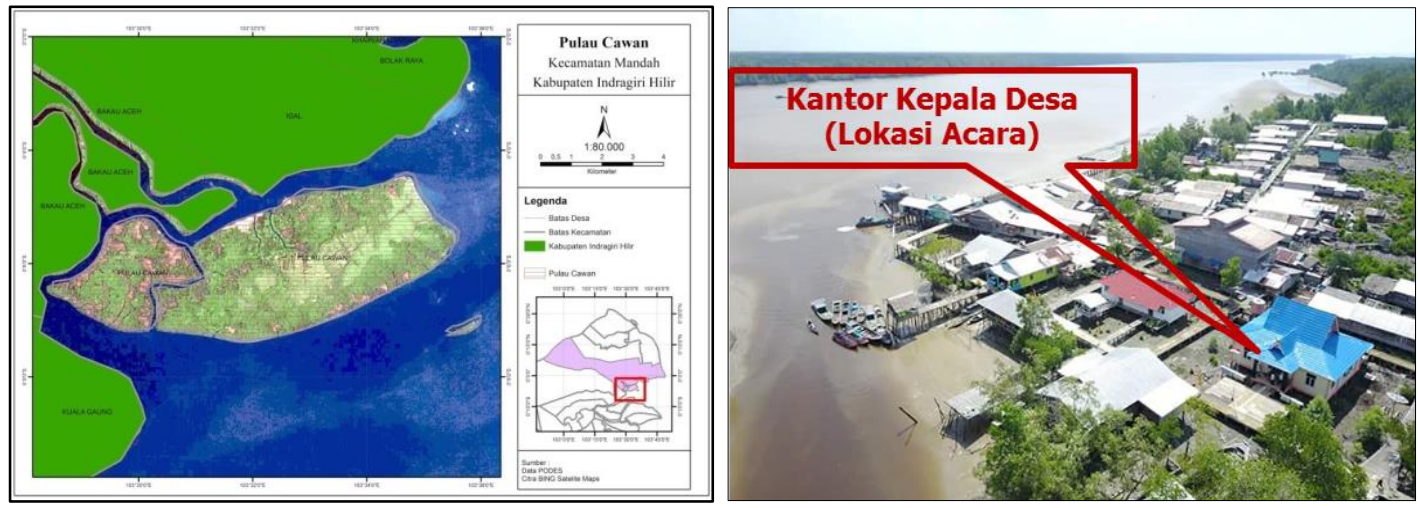

Gambar 1. Peta Pulau Cawan Indragiri Hilir dan Lokasi Kegiatan di Kantor Kepala Desa

\section{HASIL DAN KETERCAPAIAN SASARAN}

\section{Gambaran Umum Masyarakat Sasaran}

Pulau Cawan telah menjadi kawasan wisata tersembunyi yang keberadaannya di Kecamatan Mandah, Indragiri Hilir, Riau. Untuk mencapai kawasan tersebut diperlukan waktu perjalanan darat dengan jarak tempuh sekitar 7 jam dari Kota Pekanbaru menuju Tembilahan sebagai ibukota kabupaten, kemudian dilankjutkan dengan menggunakan sarana transportasi speed boat untuk menyeberangi laut selama 2 jam hingga mencapai tujuan, atau dari Kecamatan Mandah butuh waktu sekitar 30 menit menggunakan transportasi yang sama.

Belakangan ini Pulau Cawan mulai dikenal sebagai lokasi wisata menjanjikan dengan hutan mangrove dan Pantai Solopnya yang memiliki butiran pasir terbentuk dari cangkang-cangkang binatang laut dan kerangkerang putih sebagai lapisan pasir terhampar di pantai tersebut. Kawasan ini terkenal dengan potensi hasil bumi berupa kelapa dan pucuk nipah yang diolah menjadi klinting rokok untuk pasar Thailand.

Wilayah yang dulunya terkenal hanya dari hasil bumi yakni kelapa, kini mulai digandrungi alamnya oleh wisatawan lokal maupun asing seperti Malaysia dan Singapura. Jumlah kunjungan wisata ke Pulau Cawan hingga pertengahan Juli 2017 menembus 12.000 orang. Hal ini menunjukkan kenaikan hampir dua kali lipat dibanding tahun sebelumnya.

\section{Potensi Pemberdayaan Masyarakat}

Program pengabdian kepada masyarakat ini dilaksanakan di Kantor Desa Pulau Cawan yang diikuti lebih dari 30 orang peserta yang terdiri dari kader PKK perwakilan masyarakat nelayan, guru, aparat pemerintahan dan tokoh masyarakat di desa tersebut. Kegiatan penyuluhan ini dilakukan dengan melibatkan mahasiswa Kuliah Kerja Nyata dari Universitas Riau serta Dinas Kelautan dan Perikanan Kabupaten Indragiri Hilir. Tatap muka dan diskusi serta praktek pembuatan makanan dilakukan dengan melibatkan tidak hanya ibu-ibu, tetapi juga bapak-bapak yang diminta untuk mencicipi hasil olahan yang dilakukan. Prosedur pembuatan ketiga jenis makanan diserahkan kepada peserta penyuluhan sebagai bahan informasi dan panduan bagi masyarakat yang ingin melakukan usaha tersebut. Demikian juga dengan peralatan yang digunakan untuk seluruh tahapan kegiatan diserahkan kepada kader PKK yang diwakili oleh Ketua PKK dan disaksikan oleh Kepala Dinas Kelautan dan Perikanan Kabupaten Indragiri Hilir.

Banyak sekali manfaat yang dirasakan baik oleh tim penyuluh maupun oleh peserta. Lokasi penyuluhan yang cukup jauh dari Kota Tembilahan dan ditempuh melalui transortasi perahu motor selama dua jam tidak menyurutkan semangat tim penyuluh untuk berbagi ilmu dengan masyarakat. Kegiatan penyuluhan ini berjalan lancar, tertib dan aman dan para peserta sangat antusias mengikutinya dengan semangat yang tinggi dan penuh perhatian terhadap setiap materi yang disajikan.

\section{Tingkat Ketercapaian Sasaran}

Secara teknis pelaksanaan penyuluhan ini tidak mengalami hambatan yang berarti karena pelaksanaannya dilakukan melalui perencanaan yang telah disusun sedemikian rupa sehingga pada saat penyuluhan dilakukan semua peserta dapat hadir di lokasi penyuluhan dan mengikuti semua program sebagaimana yang telah direncanakan. Meskipun pengetahuan peserta yang mengikuti kegiatan penyuluhan tersebut masih terbatas, 
namun secara keseluruhan mereka akhirnya dapat memahami materi yang disuluhkan. Peserta bahkan mengharapkan kegiatan serupa dapat dilakukan lagi dan memohon bantuan kiranya untuk disampaikan kepada pemerintah agar dapat memberikan bantuan selanjutnya.

Kehadiran peserta dari kader PKK dan ibu-ibu rumah tangga yang cukup banyak dalam kegiatan ini juga merupakan indikasi bagaimana masyarakat berkeinginan untuk mengembangkan usaha kecil yang dapat membantu peningkatan taraf hidup keluarga melalui usaha sampingan dengan memanfaatkan potensi dan sumberdaya ikan yang ada di daerah mereka. Beberapa kegiatan dan produk yang dihasilkan dapat dilihat pada Gambar 2.
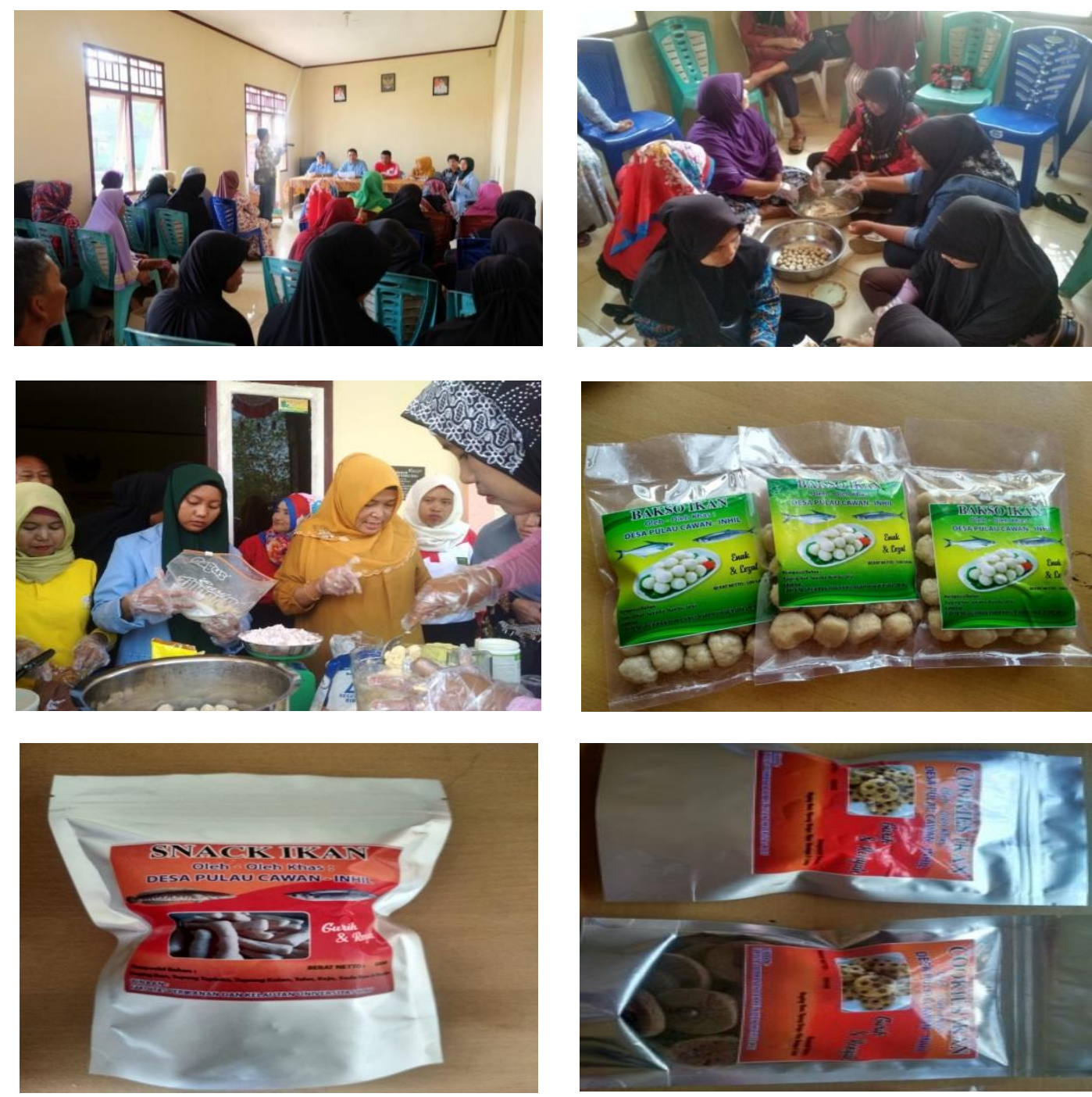

Gambar 2. Pelaksanaan kegiatan di Kantor Kepala Desa dan produk siap jual yang dihasilkan

Kegiatan yang pelaksanaannya dilakukan dengan kerjasama mahasiswa peserta Kuiliah Kerja Nyata mendapatkan sambutan yang baik dari masyarakat desa, terutama kader PKK, Kepala Desa dan juga dari Kepala Dinas Kelautan dan Perikanan Kabupaten Indragiri Hilir. Kehadiran peserta melebihi yang ditargetkan dan Kader PKK sudah dapat membuat makanan berbahan dasar ikan sebagaimana yang diajarkan oleh tim pengabdian dan hasil dari produk olahan yang dihasilkan dirasakan oleh seluruh peserta dan sebahagian lagi dibawa pulang oleh peserta, termasuk perwakilan dari Humas Pemkab Inhil, media dan Dinas Kelautan dan Perikanan Indragiri Hilir. Kepala Dinas Kelautan dan Perikanan bahkan berjanji akan memberikan bantuan lebih luas bagi pengembangan produksi yang dihasilkan tersebut, termasuk membantu pemasarannya. Untuk keberlanjutan usaha, maka peralatan yang digunakan untuk kegiatan produksi makanan berbahan ikan tersebut diserahkan kepada Kader PKK Desa Pulau Cawan. Kegiatan pengabdian kepada masyarakat ini juga diliput dan disiarkan melalui media massa, baik televisi dan beberapa media cetak serta media online. Prosedur pembuatan produk makanan berbasis ikan yang diajarkan kepada masyarakat juga didistribusikan. Kepala 
Dinas Kelautan dan Perikanan Kabupaten Indragiri Hilir juga berjanji akan memberikan bantuan fasilitas kepada kader PKK untuk memasarkan produk yang dihasilkan di ibukota kabupaten Indragiri Hilir.

\section{KESIMPULAN}

Kegiatan penyuluhan ini dirasakan sangat besar manfaatnya sebagaimana yang diungkapkan oleh peserta, Kepala Desa dan juga Kepala Dinas Kelautan dan Perikanan Kabupaten Indragiri Hilir kepada media televisi, media sosial dan media cetak yang dipublikasikan ke masyarakat umum. Keadaan tersebut juga dapat dilihat dari keseriusan peserta dalam mengikuti kegiatan penyuluhan yang telah membuka cakrawala berfikir para peserta dalam memahami pemanfaatan hasil perikanan yang dapat menjadi nilai tambah secara ekonomi dengan memanfaatkan keterampilan dan pengembangan jiwa kewirausahaan. Masyarakat juga dapat memahami pemanfaatan pengolahan hasil perikanan disamping untuk meningkatkan gizi, juga dijadikan oleholeh bagi wisatawan berupa makanan khas dan dapat meningkatkan penghasilan untuk memperbaiki taraf hidup masyarakat. Untuk menjaga agar masyarakat terus melakukan usaha pengolahan hasil perikanan, kiranya pihak pemerintah daerah dapat memberikan bantuan berupa pelatihan-pelatihan dan penyediaan sarana dan prasarana pengolahan hasil perikanan di kawasan pesisir pantai Desa Pulau Cawan dan wilayah pesisir Kabupaten Indragiri Hilir.

\section{UCAPAN TERIMAKASIH}

Ucapan terima kasih disampaikan kepada Rektor Universitas Riau melalui Lembaga Penelitian dan Pengabdian kepada Masyarakat yang telah menyediakan Dana Pengabdian Kepada Masyarakat tahun 2018 Skim Desa Binaan. Ucapan terima kasih juga disampaikan kepada Kepala Dinas Kelautan dan Perikanan Kabupaten Indragiri Hilir, Kepala Desa Pulau Cawan dan jajarannya serta Dosen Pembimbing Lapangan (DPL) dan Mahasiswa KKN yang telah berpartisipasi dalam kegiatan ini.

\section{DAFTAR PUSTAKA}

Adawyah, R. 2007. Pengolahan dan Pengawetan Ikan. Jakarta: Bumi Aksara.

Dewita, dan Syahrul. 2010. Kajian konsentrat protein ikan patin dan masa simpannya dalam kemasan berbeda. Laporan Penelitian Hibah Kompetensi Tahun 2010. Lembaga Penelitian Universitas Riau (tidak dipublikasikan).

DKP Inhil. 2016. https://news.kkp.go.id/index.php/potensi-perikanan-tangkap-indragiri-hilir-capai-111-212-ton Diakses pada 12 April 2016.

Manley, D. 2000. Technology of Biscuits, Crackers and Cookies. Woodhead Publishing Ltd. Cambridge.

Potretnews.com, 2016. Dialami 21 anak jumlah kasus gizi buruk di Inhil terbanyak di Riau. https://www.potretnews.com/berita/baca/2016/04/19/dialami-21-anak-jumlah-kasus-gizi-buruk-di-inhilterbanyak-di-riau Diakses pada 18 Februari 2019.

Syahrul, Dewita, \& Restu. 2018. Implementasi pewarna alami untuk diversifikasi mie sagu ikan pada pelaku usaha mikro mie sagu di Kabupaten Kepulauan Meranti, Riau. Riau Journal of Empowerment 1(1): 31-36. https://doi.org/10.31258/raje.1.1.4 